\title{
Analisis Sistem Pengendalian Intern Terhadap Prosedur Penjualan dan Penerimaan Kas Pada PT. Nusa Sarana Citra Bakti (Suzuki) Palembang
}

\author{
Pradistiara Muhammad Amnesti ${ }^{1}$, Oktariansyah $^{2}$, Ermini $^{3}$ \\ ${ }^{1}$ Fakultas Ekonomi dan Bisnis Universitas PGRI Palembang, pradismuhammad70@gmail.com \\ ${ }^{2}$ Fakultas Ekonomi dan Bisnis Universitas PGRI Palembang, rianbro82@univpgri-palembang.ac.id \\ ${ }^{3}$ FKIP Universitas PGRI Palembang, servaldae@gmail.com
}

\begin{abstract}
This study aims to analyze the Internal Control System Against Sales Procedures and Cash Receipts at PT. Nusa Sarana Citra Bakti (Suzuki). This research is a qualitative research using program evaluation. The design of this research is descriptive-analysis. Data collection techniques using documentation and study of literature. Data analysis techniques used data triangulation with (1) data reduction, (2) data presentation, (3) conclusion drawing. The results of this study are in the process of accounting, the company has used adequate accounting media in the form of basic documents, journal books, ledgers, supporting books. For the classification process, the company has also used an estimate code where the estimated code has been standardized in the form of a guidebook that is accompanied by an explanation of its use. Reporting from the accounting information system for sales and cash receipts consists of external reports and internal management reports. Conclusion: Internal control system of the procedures for selling and receiving cash at PT. Nusa Sarana Citra Bakti (Suzuki) Palembang can be declared good because the procedure is in accordance with their respective duties and functions.
\end{abstract}

Keywords: Internal Control System, Cash Sales and Receipts

\begin{abstract}
ABSTRAK
Penelitian ini bertujuan untuk menganalisis Sistem Pengendalian Intern Terhadap Prosedur Penjualan dan Penerimaan Kas Pada PT. Nusa Sarana Citra Bakti (Suzuki). Penelitian ini adalah penelitian kualitatif dengan menggunakan evaluasi program. Desain penelitian ini adalah deskriptif-analisis. Teknik pengumpulan data menggunakandokumentasi dan study pustaka. Teknik analisis data menggunakan triangulasi data dengan (1) reduksi data, (2) penyajian data, (3) penarikan kesimpulan. Hasil penelitian ini yaitu dalam proses akuntansinya, perusahaan telah menggunakan media akuntansi yang memadai berupa dokumen dasar, buku jurnal, buku besar, buku pembantu. Untuk proses pengklasifikasian, perusahaan juga telah menggunakan kode perkiraan dimana kode perkiraan telah dibakukan dalam bentuk buku pedoman yang dilengkapi dengan penjelasan penggunaannya. Pelaporan dari sistem informasi akuntansi penjualan dan penerimaan kas terdiri dari laporan ekstern dan laporan intern manajemen. Simpulan: Sistem pengendalian intern terhadap prosedur penjualan dan penerimaan kas pada PT. Nusa Sarana Citra Bakti (Suzuki) Palembang dapat dinyatakan sudah baik karena pada prosedur tersebut sudah sesuai dengan tugas dan fungsinya masing-masing.
\end{abstract}

Kata Kunci : Sistem Pengendalian Intern, Penjualan dan Penerimaan Kas

\section{A. PENDAHULUAN}

Perusahaan yang memiliki sistem pengendalian internal yang baik adalah perusahaan yang mampu memisahkan tanggung jawab fungsional secara tegas, sistem otorisasi dan prosedur pencatatan yang baik, dan sumber daya yang memadai. Sistem pengendalian intern bukanlah sebuah sistem yang dimaksudkan untuk menghindari semua kemungkinan terjadinya kesalahan ataupun 
penyelewengan yang terjadi. Sistem pengendalian intern yang baik adalah dimana sebuah perusahaan dapat menekan terjadinya kesalahan dan penyimpangan yang mungkin terjadi. Fungsi pengendalian yang baik dengan berlandaskan pada system manajemen dan keuangan yang baik pula akan menciptakan aktivitas dalam perusahaan menjadi lancar dan terkendali (Anastasia dan Lilis, 2010:82 dalam Rannita M. Manoppo, 2013).

Sistem penjualan dan penerimaan kas merupakan sistem inti yang berpengaruh besar terhadap keberhasilan suatu perusahaan karena penjualan merupakan kegiatan bisnis yang dilakukan perusahaan untuk dapat memperoleh keuntungan sedangkan penerimaan kas merupakan ukuran awal laba yang diterima perusahaan yang menurut karakteristik dan fungsinya, kas merupakan alat yang mudah untuk disalahgunakan oleh pihak-pihak yang kurang bertanggung jawab. Kas dalam neraca merupakan kas yang paling liquid, karena hampir setiap transaksi yang dilakukan oleh fungsi yang berwenang atau yang terkait di dalam perusahaan maupun dengan pihak luar yang sebagian besar akan mempengaruhi kas. Kas bersifat mudah dipindahtangankan sehingga kas merupakan aktiva yang rawan, karena mudah digelapkan dan dimanipulasi. Keadaan ini akan mendorong perusahaan untuk melakukan penataan pada sistem penerimaan kas yang meliputi beberapa aspek yang saling berkaitan (Any Krisnawati Suhadak Topowijono, 2013).

Pada dasarnya setiap perusahaan memiliki tujuan untuk memperoleh laba baik itu perusahaan industri, dagang maupun jasa yaitu dengan melaksanakan kegiatan penjualan. Transaksi penjualan yang dilakukan oleh perusahaan secara tunai maupun kredit akan mengakibatkan adanya penerimaan kas. Penerimaan kas merupakan transaksi yang menyebabkan asset perusahaan yang berupa kas bertambah guna mendukung pertumbuhan dan pekembangan perusahaan, perusahaan membutuhkan suatu sistem yang dapat digunakan oleh perusahaan untuk pemrosesan dan pengelolahan data penjualan dan penerimaan kas agar dapat berjalan dengan baik yaitu dengan sistem akuntansi dan pengendalian intern untuk pengawasan.

Perusahaan harus melakukan evaluasi terhadap pelaksanaan sistem dan prosedur distribusi penjualan yang telah dilakukan olehperusahaan dengan cara pembagian tugas dan wewenang sehingga dapat tercipta internal check dalam setiap unit perusahaan dan menghasilkan data akuntansi yang dapat dijadikan sebagai bukti transaksi (Ma'roep dalam Ivan Setyo Bahari, 2017).

Analisis terhadap sistem pengendalian inter terhadap penjualan dan penerimaan kas diperlukan agar dalam menjalankan kegiatannya perusahaan lebih efektif dan efisien. Adanya analisis memungkinkan adanya kelemahan dan kelebihan dari sistem informasi akuntansi tersebut.

\section{B. KAJIAN PUSTAKA Sistem Pengedalian Intern}

Tujuan penerapan pengendalian intern bagi perusahaan yang dikemukakan oleh Mulyadi (dalam Oktariansyah, 2015) dalam pemeriksaan akuntansi sebagai berikut :

1) Menjaga kekayaan dan catatan organisasi.

Kekayaan fisik yaitu suatu perusahaan dapat dicuri, disalah gunakan atau hancur karena kecelakaan, kecuali jika kekayaan tersebut dilindungi dengan pengendalian yang memadai. Begitu juga untuk kekayaan perusahaan yang tidak memiliki wujud fisik, seperti piutang dagang, akan rawan oleh kecurangan 
jika dokumen piutang (kontrak penjualan) dan catatan akuntansi (kartu piutang) tidak dijaga.

2) Mengecek ketelitian dan keandalan data akuntansi

Manajemen memerlukan informasi keuangan yang teliti dan andal untuk menjalankan kegiatan usahanya. Banyak informasi akuntansi yang digunakan manajemen untuk mengambil dasar keputusan yang penting. Pengertian intern dirancang untuk memberikan jaminan proses pengolahan data akuntansi untuk menghasilkan informasi keuangan yang teliti dan handal. Ketelitian dan keandalan data akuntansi mencerminkan perubahan terhadap kekayaan perusahaan, maka ketelitian dan keandalan data akuntansi merefleksikan pertanggung jawaban penggunaan kekayaan.

3) Mendorong Efisiensi

Pengendalian intern ditujukan untuk mencegah duplikasi usaha yang tidak perlu atau pemborosan akan segala kegiatan bisnis perusahaan, juga ditujukan untuk mencegah penggunaan sumber daya perusahaan yang tidak efisien.

4) Mendorong dipatuhinya kebijaksanaan manajemen

Untuk mencapai tujuan perusahaan, manajemen menetapkan kebijaksanaan dan prosedur. Struktur pengendalian intern ditujukan untuk memberikan jaminan yang memadai agar kebijaksanaan manajemen dipatuhi oleh karyawan perusahaan.

\section{Sistem dan Prosedur}

Menurut Mulyadi (2008:5) dalam Astria Dewi (2017) pendekatan sistem yang lebih menekankan pada prosedur mendefinisikan sistem sebagai "suatu sistem adalah suatu jaringan yang saling berhubungan, berkumpul bersama-sama untuk melakukan suatu kegiatan atau untuk melakukan suatu kegiatan atau untuk menyelesaikan suatu sasaran tertentu".

Sedangkan prosedur menurut Yodianto (dalam lbnu Hanny, 2013) mendefinisikan sebagai "suatu prosedur adalah urut-urutan yang tepat dari tahapantahapaninstruksi yang menerangkan apa (what) yang harus dikerjakan, siapa (who) yang mengerjakan, kapan (when) dikerjakan, dan bagaimana (how) mengerjakannya".

\section{Kas}

Menurut Ikatan Akuntansi Indonesia bahwa "Kas terdiri dari saldo kas (cash and hand) dan rekening giro serta kas (cash equivalent) adalah investasi yang sifatnya sangat likuid berjangka pendek dan yang dengan cepat dapat dijadikan kas dalam jumlah tertentu tanpa menghadapi resiko perubahan-perubahan yang signifikan." (IAI, 2012:22). Adapun fungsi kas adalah sebagai berikut :

1. Membiayai kegiatan operasional perusahaan.

2. Sebagai alat tukar pembayaran.

3. Alat yang diterima sebagai net bank sebagai nilai nominal.

4. Sebagai investasi baru dalam aktiva tetap.

\section{Prosedur Penerimaan Kas}

Menurut Bodnar dan Hopwood (dalam Lisa Amelia Herman, 2013) menjelaskan bahwa tujuan dasar setiap aplikasi penerimaan kas adalah meminimalkan kemungkinan kerugian. Prosedur-prosedur seperti penyimpanan segera penerimaan kas, sentralisasi penanganan kas, penyelenggaraan saldo kas minimal, dan 
pencatatan segera atas transaksi-transaksi kas merupakan teknik-teknik pengendalian yang mendasar. Perlindungan fisik seperti register kas, kotak penyimpanan, pencairan segera atas cek dan akses terbatas terhadap area kas meupakan hal yang juga sangat umum diperlukan. Dalam pencatatan transaksi penerimaan kas ini dikenal buku harian penerimaan kas (cash receiptjournal) sebagai media pencatatan, pada umumnya penerimaan kas perusahaan yang utama adalah dari penjualan tunai dan penerimaan piutang, disamping itu juga terdapat sumber penerimaan kas lainnya seperti pinjaman dari kreditur, pendapatanbunga, penjualan aktiva tetap, dan sebagainya.

\section{Kerangka Pemikiran}

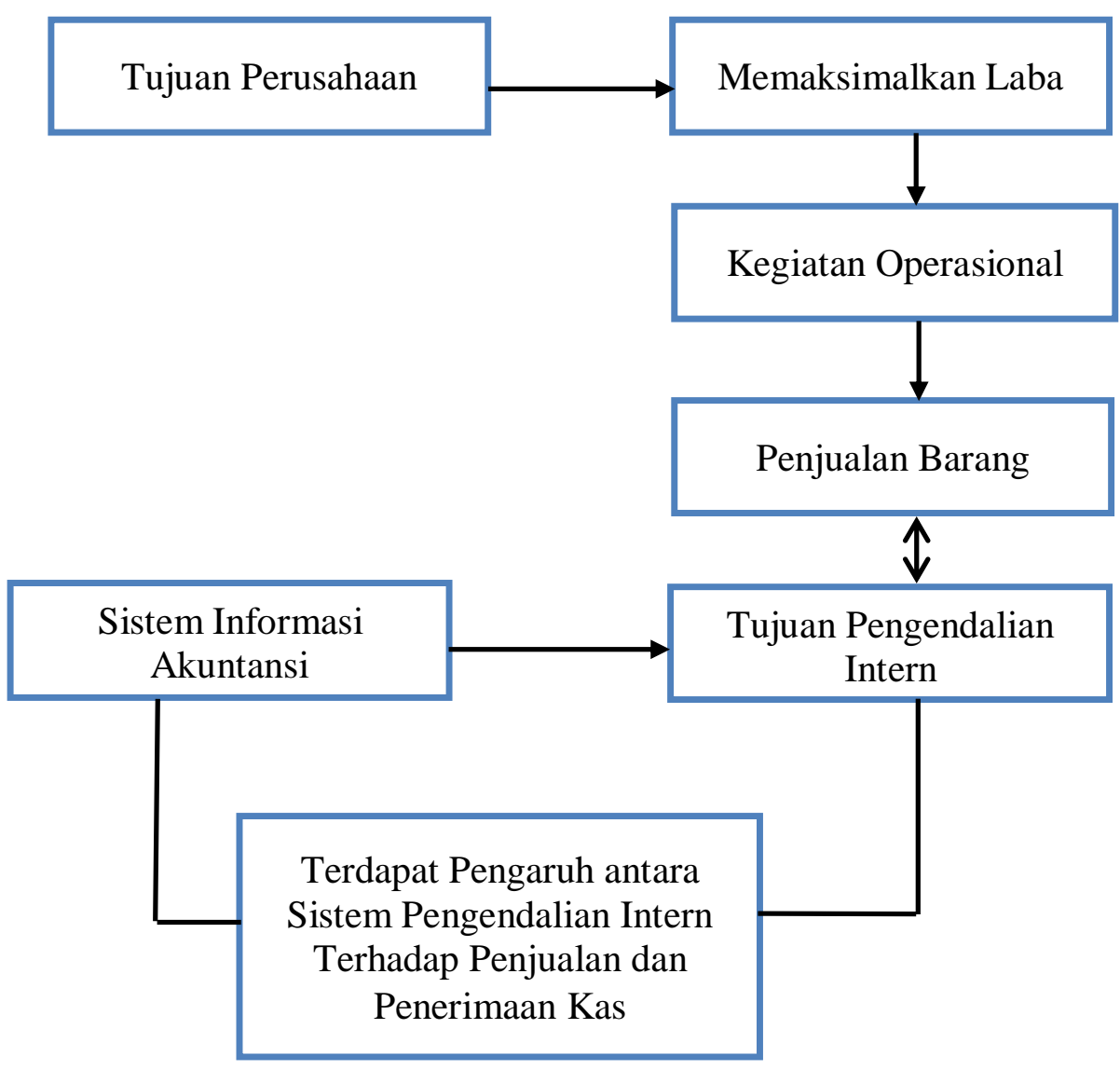

\section{METODE PENELITIAN}

Penelitian ini dilakukan di PT. Nusa Sarana Citra Bakti (SUZUKI) Di Km. 7 Kolonel H. Burlian Palembang, Sumatera Selatan. Jenis penelitian yang digunakan dalam penelitian ini adalah penelitian Kuantitatif. Sistem Pengendalian Intern (Variabel X), Penjualan dan Penerimaan Kas (Variabel Y). Populasi dalam penelitian ini yaitu konsumen, admin kasir, dan Branch Manager pada penjualan dan penerimaan kas pada PT. Nusa Sarana Citra Bakti (SUZUKI) di Palembang. Sampel pada penelitian ini yaitu sistem prosedur dan penerimaan kas PT. Nusa Sarana Citra Bakti (SUZUKI) di Palembang. Dalam penelitian ini, yang menjadi responden atau subyek penelitian adalah Administration and Finance Coordinator. Data yang digunakan dalam penelitian ini adalah data primer dan data sekunder dengan teknik 
dokumentasi yaitu mengumpulkan dokumen dan catatan yang dimiliki PT. Nusa Sarana Citra Bakti (SUZUKI) di KM 7 Kolonel $\mathrm{H}$. Burlian Palembang yang mendukung terjadinya proses pelaksanaan sistem pengendalian internal terhadap penerimaan kas seperti faktur penjualan tunai, pita register kas, jurnal, kartu persediaan serta kartu gudang, dll serta melakukan studi pustaka untuk mendapatkan informasi yang diperlukan peneliti mengetahui sumber-sumber informasi tersebut, misalnya kartu katalog, referensi umum dan khusus, buku-buku pedoman, buku petunjuk, laporan-laporan penelitian, tesis, disertasi, jurnal, ensiklopedi, dan bahan-bahan khusus lain.

Peneliti melakukan pengumpulan data-data yang dianggap membantu dalam membantu memberikan informasi yang berkaitan dengan penelitian.Kemudian datadata tersebut direduksi dengan melakukan proses seleksi, pemfokusan, penyederhanaan dan abstraksi data dari fieldnote (catatan lapangan). Proses ini berlangsung terus sepanjang penelitian sampai laporan akhir untuk mempertegas, mempermudah dan membuat fokus, membuang hal yang tidak penting, serta mengatur data sehingga kesimpulan akhir dapat dilakukan. Lalu setelah reduksi data peneliti menyajikan data yaitu merakit informasi secara teratur agar mudah dilihat dan dimengerti dalam bentuk yang kompak. Setelah data tersajikan, maka peneliti menarik kesimpulan dari data-data yang diperoleh dari awal hingga akhir pencarian. Dalam melakukan penarikan kesimpulan peneliti bersikap terbuka artinya apabila pada akhir penelitian menemukan data yang kurang akurat, peneliti tidak segan-segan untuk mengadakan penyimpulan ulang.

\section{HASIL PENELITIAN}

\section{Sistem Pengendalian Intern Penjualan dan Penerimaan Kas di PT. Nusa Sarana Citra Bakti (Suzuki) Palembang}

1. Otorisasi (Pengesahan Transaksi)

Sistem otorisasi pada prosedur pengambilan kwitansi yang akan ditagih setelah dilakukan perhitungan fisik dan disertai berita acara serah terima yang ditandatangani oleh kedua belah pihak, begitu juga dengan sistem otorisasi prosedur dalam pengemblian kwitansi yang tidak berhasil ditagih oleh pihak, juga disertai berita acara serah terima oleh kedua belah pihak.

\section{Pemisahan Tugas}

Struktur organisasi ditandai dengan adanya pemisahan fungsi antara bagain pemasaran, bagian keuangan dan bagian akuntansi, serta fungsi penerimaan kas. Fungsi pencatatan dan penyimpanan harus mendapat pemisahan tugas dan tisak terdapat satu orang yang bertanggung jawab terhadap duakegiatan tersebut.

\section{Supervisi (Pengawasan)}

Pegawai yang bekerja melakukan tugasnya sesuai dengan tugas dan tanggung jawabnya yang terdapat dalam deskripsi kerja, serta jumlah pegawai yang dibutuhkan disetiap bagian harus memadai sesuai dengan fungsi yang ada sehingga pelaksanaan supervisi tidak terlalu dominan dan tidak terlalu memerlukan supervisi dalam pelaksanaan tugas operasional setiap bidang yang ada dalamperusahaan.

\section{Catatan Akuntansi}

Penggunaan dokumen dan catatan yang berisi dan dinomori terlebih dahulu telah dilakukan terhadap formulir-formulir dan catatan seperti order pembelian dan yang lainnya telah disiapkan pada saat transaksi terjadi. 
Untuk dapat melindungi dan mengamankan aktiva dan catatannya, PT. Nusa Sarana Citra Bakti (Suzuki) Palembang melakukan pengendalian yang meliputi:

1) Penggunaan gudang untuk menyimpan persediaan barang-barang dari pencurian dan menempatkan penjaga untuk mengamankan gudang.

2) Perusahaan juga telah melakukan pengamanan data dengan melakukan back up data kedalam $C D$ dan Flasdisk untuk mengantisipasi apabila terjadi kerusakan terhadap komputer.

3) Penyetoran uang kas secara harian kebank

4) Penggunaan kotak penyimpanan uang kas yangaman.

5) Pengamanan laci kas dengan melakukan penguncian pada bagianloket.

\section{Sistem Informasi Akuntansi Penjualan dan Penerimaan Kas di PT. Nusa Sarana Citra Bakti (Suzuki) Palembang}

PT. Nusa Sarana Citra Bakti (Suzuki) Palembang menerapkan Sistem informasi akuntasi penjualan dan penerimaan kasmasih secara manual terhadap pencatatan dan pelaporan informasi akuntansi. Proses pencatatan dan pelaporan informasi akuntansi dilakukan dengan sistem manual yang dilakukan secara bulanan. Maka setiap bulan bagian akunting membuat laporan secara berkala kepadadirektur.

\section{Sistem Penjualan}

Jenis penjualan ada dua macam, yaitu penjualan tunai dan penjualan kredit. Oleh karena itu, berdasarkan penelitian yang telah penulis lakukan pada PT. Nusa Sarana Citra Bakti (Suzuki) Palembang, maka prosedur penjualan dilakukan sebagai berikut:

a) Penjualan Kredit

1. Setiap penjualan dalam perusahaan ini akan selalu dimulai dengan adanya order pelanggan yang diterima oleh sales departemen (bagaian penjualan) untuk kemudian dikonfirmasikan ke bagian akuntansi. Order dapat dilakukan melalui telepon atau langsung datang ke kantor, lalu bagian penjualan melakukan tindak lanjut dengan order yang ada.

2. Bagian akuntansi kemudian mempersiapkan tanda terima yang diberi nama Proof of Delivery (POD) dimana setiap POD mempunyai nomor tercetak berurutan yang berisi alamat pengirman, alamat penerima, jenis barang, volume atau jumlah barang yang akan dikirim. POD ini terdiri dari lima warna yaitu:

$$
\begin{array}{lll}
> & \text { Putih } & \text { : diberikan untuk pelanggan } \\
>\text { Biru } & \text { : diberikan kepda bagian operasinal } \\
> & \text { Kuning } & \text { : merupakan return copy ditempelkan dibarang } \\
> & \text { Hijau } & \text { : diberikan kepada akunting } \\
>\text { Merah } & \text { : diberikan kepada penerima }
\end{array}
$$

Untuk penjualan kredit ini, pelanggan menerima POD lembar kelima yaitu yang berwana merah.

3. Setelah dilakukan pengecekan barang, besarnya tarif dan cara pembayaran kredit. Tanda terima pada pelanggan akan berfungsi sebagai bukti bagi perusahaan untuk melakukanpenagihan.

4. POD lembar pertama dan ketiga diberikan kepada bagian akunting sebagai bukti bahwa telah terjadi penjualan secara kredit oleh bagianpenjualan.

5. Barang yang telah disetujui akan dikirim, kemudian oleh bagian gudang 
dilakukan pengepackan barang untuk dipersiapkan atau diberi label oleh bagian operasional untuk dikirim sesuai dengan pesanan pelanggan. POD lembar kedua yang berwarna biru dan POD yang berwarna kuning, dilekatkan pada barang tersebut. Adapun tujuan yaitu untuk menjadi bukti bahwa barang telah dikrim dan telah tiba dengan selamat dan tepat waktu berdasarkan alamat pelanggan.

Setiap pada waktu sore hari, bagian penjualan menyampaikan daftar penjualannya baik yang dilakukan secara tunai maupun secara kredit kepada bagian akuntansi.

\section{b) Penjualan Tunai}

Berdasarkan data yang ada dilapangan, sebagian besar penjualan dilakukan secara tunai. Penjualan secara tunai adalah penjualan yang dilakukan di kantor, dimana pelanggan langsung datang ke kantor membeli barang dan langsung membayar dengan uang tunai. Prosedur penjualan secara tunai dijelaskan secara berikut:

1. Pelanggan datang langsung ke kantor, bagian customer services melayani mereka dengan memberikan daftar harga. Setelah pelanggan menyetujui harga yang ditetapkan maka bagian gudang mencekpenyediaan.

2. Bagian akuntansi mengeluarkan POD yang terdiri lima rangkap kepada bagian Costumer Services agar dilakukan pengisianPOD.

3. Pelanggan membayar tunai sesuai dengan yang tertera pada $P O D$, dan menerima lembaran pertama POD (berwarna putih).

4. Customer Services menyetorkan uang dari pelanggan tersebut kepada kasir dengan memberikan lembaran ketiga sebagai bukti, lalu meneruskannya kebagian akunting agar dilakukan pencatatan. Perludi ketahui bahwa POD ini dapat berfungsi sebagi kwitansi dalam penjualan tunai.

\section{Sistem Penerimaan Kas}

Prosedur penerimaan kas dari penjualan tunai dan penjualan kredit yang dilakukan pada PT. Nusa Sarana Citra Bakti (Suzuki) Palembang yaitu sebagai berikut :

a) Penerimaan Kas dari Penjualan Tunai

Seperti yang telah dijelaskan pada prosedur penjualan tunai, penerimaan kas pada PT. Nusa Sarana Citra Bakti (Suzuki) Palembang setiap penjualan barang dalam perusahaan ini selalu dimulai dengan adanya order yang diterima oleh bagian penjualan untuk kemudian dikonfirmasikan ke bagian akuntansi apakah order diterima atau tidak. Setelah itu bagian akuntansi mempersiapkan POD untuk menjadi bukti transaksi apakah dilakukan penjualan secaratunai.

Jika terjadi penjualan secara tunai, maka bagian penjualan akan langsung menerima uang tersebut pada saat itu juga, dengan menyerahkan lembar pertama dari POD (yang berwarna putih) kepada pelanggan. Lalu bagian penjualan akan melaporkan jumlah penerimaan kas hariannya kepada kasir sekaligus menyerahkan POD lembar ketiga dan kelima sambil menyetorkan uangnya. Kasir memeriksa POD tersebut dan meneruskannya kebagian akuntansi untuk dilakukan pencatatan dan membandingkannya dengan laporan penjualan tunai.

b) Penerimaan Kas dari Pelanggan oleh Collector

Penagihan collector ini dilakukan jika terjadi penjualan secara kredit, maka bagian penjualan memberikan POD lembar kelima kepada pelanggan sebagai bukti 
sementara, sedangkan pelanggan memberikan tanda terima kepada bagian penjualan sebagai bukti untuk penagih (collector). POD lembar pertama dan ketiga menjadi pertinggal bagi bagian akuntansi yang akan menjadi bukti transaksi penjulan kredit. POD tersebut dikumpulkan dan dicatat dalam laporan penjualan kredit oleh bagian akuntansi, dimana pada setiap akhir bulan akan dilaporkan kepada atasan. Laporan ini pada awal bulan akan diperiksa kembali untuk melihat piutang yang telah jatuh tempo dan dasar melakukan penagihan.

Apabila piutang telah jatuh tempo dan pelanggan belum mengadakan pembayaran maka bagian akunting akan menyerahkan POD lembar pertama beserta tanda terima dari pelanggan yang telah jatuh tempo tersebut kebagian penjualan (sales departemen) untuk dilakukan penagihan ke tempat pelanggan. Pelanggan menyerahkan uang pembayarannya beserta POD lembar kelima kepada collector dan collector menyiapkan tanda terima yaitukwitansi.

Setelah uang diterima, maka collector akan menyerahkan lembar pertama (berwarna putih) kepada pelanggan setelah diisi dengan nomor POD (nomor pengiriman) dan ditandatangai oleh kedua belah pihak.Collector melaporkan jumlah penerimaan piutang yang ditagihnya ke kasir sekaligus menyerahkan kwitansi lembar kedua dan lembar ketiga beserta POD lembar pertama dan menyetorkan uangnya. Kasir memeriksa kwitansi dan POD tersebut dan meneruskannya ke bagian akunting untuk dicatat dalam buku penerimaan kas dan mengurangi penjualan kredit.

c) Membayar dengan Giro/ Transfer ke Rekening Perusahaan

Apabila pelanggan membayar dengan cara mentransfer ke rekening perusahaan, maka akan diadakan pengecekan ke bank. Tetapi sebelumnya pelanggan akan menginformasikannya ke bagian penjualan. Selanjutnya kasir membuat bukti penerimaan kas tanpa harus diotorisasi oleh direksi atau langsung dibukukan.Tugas kasir apabila ditinjau dari segi penerimaan kas adalah sebagai berikut:

$\checkmark$ Membuat buku kas setiaphari

$\checkmark$ Mengumpulkan bon-bon yang berkaitan dengan buku hariantersebut.

$\checkmark$ Membuat laporan keperluan dana setiap bulan sepertikasbon

$\checkmark$ Membuka giro atau cek (data dari bagianakunting).

\section{E. PEMBAHASAN}

\section{Analisis Sistem Pengendalian Intern Terhadap Prosedur Penjualan dan Penerimaan Kas Pada PT. Nusa Sarana Citra Bakti (Suzuki) Palembang}

Sistem merupakan cara atau langkah yang dipergunakan untuk melaksanakan kegiatan agar sesuai dengan kebijakan yang telah ditetapkan. Sistem juga merupakan salah satu sarana pengendalian manajemen yang penting, dalam pelaksanaan suatu prosedur secara adminstrasi dibantu dengan berbagai formulir atau blanko yang telah dirancang sehingga prosedur yang dilaksanakan tercatat dan tampak dalam pengisian blanko tersebut.

Untuk mewujudkan adanya sistem informasi penjualan dan penerimaan kasyangbaik,sistempenjualandanpenerimaankasyangditerapkanharus

memperhatikan prinsip-prinsip pengendalian intern,sehingga tujuan pengendalian itern atas penjualan dan penerimaan kas padaPT. Nusa Sarana Citra Bakti (Suzuki) Palembang dapat tercapai., 


\section{Prosedur Penjualan}

Perusahaan menetapkan bahwa apabila ada order dari pelanggan maka disetujui bagian akunting terlebih dahulu, kemudian diterbitkan POD dalam beberapa rangkap yang tembusannya diberikan kepada pelanggan, akunting dan operasional. Dari prosedur diatas dapat dilihat bahwa sales order yang ada harus disetujui oleh bagian akunting. Secara teori dapat kita lihat pengawasan yang baik terhadap kontrol pemberian kredit, tetapi secara praktik hal ini belum terlaksana karena adanya perangkapan tugas dan fungsi dalam bagian penjualan, dan akunting. Maka dalam hal ini penyelewengan dan kecurangan sangat rentan terjadi dan dapat menimbulkan piutang taktertagih.

\section{Prosedur Penerimaan Kas}

Kas yang telah diterima dari collector pada perusahaan ini tidak semua langsung disetorkan ke bank pada hari itu juga. Hal ini telah menunjukkan bahwa kerugian-kerugian yang mungkin akan terjadi pada perusahaan adalah sebagi berikut:

a) Kemungkinan kerugian karena adanya pencurian atau bencana kebakaran;

b) Tidak mendapat jasa giro.

Selain itu dalam prosedur penerimaan kas perusahaan ini terdapat kelemahan yaitu: kasir merangkap sebagai bagian pencatatan dan menyetorkan ke bank yang seharusnya mencatat adalah tugas yang dilakukan oleh bagian akunting, sehingga kemungkinan untuk melakukan kecurangan. Hal ini berarti dalam menciptakan prosedur penerimaan kas dan pencatatannya agar dapat menghasilkan informasi yang handal, maka perusahaan harus menerapkan prinsip-prinsip pengendalian intern yang memberikan jaminan bahwa semua penerimaan telah dicatat dan diterima, sehingga semua uang yang harus diterima telah seluruhnya disetorkan ke bank.

Untuk memenuhi tujuan perusahan perlu didukung hal-hal sebagai berikut:

a) Tidak ada seorang petugaspun yang menangani suatu transaksi dari awal sampai akhir;

b) Penerimaan kas segera dicatat dengantepat;

c) Semua penerimaan uang harus disetorkan ke bank pada hari itu juga atau paling lambat satu hari kerjaberikutnya.

d) Penerimaan dikontrol dengan menggunakan sarana yang memadai seperti pemakaian formulir yang diberi nomor urut terlebih dahulu, penggunaan kas dan alat-alat mekanis lainnya.

\section{Pencatatan dan Pelaporan}

Akuntansi merupakan metode pengendalian financial yang penting terhadap kegiatan-kegiatan sumber dan pertanggungjawaban pada bidang-bidang tertentu. Kegiatan-kegiatan akuntansi tersebut akan menghasilkan produk yang tentunya sangat mempengaruhi proses operasi perusahaan. Produk akuntansi tersubut bernama laporan keuangan yang terdiri atas neraca, laporan laba rugi, laporan saldo laba, laporan arus kas ditambah dengan catatan laporan akuntansi. Laporan keuangan ini akan menggambarkan keadaan perusahaan terutama keadaan keuangan dan kinerja perusahaan yang sangat berpengaruh pada kelanjutan perusahaan dimasa yang akan datang.

Uraian tersebut di atas, dapat diketahui pencatatan dan proses sistem informasi 
akuntansi penjualan dan penerimaan kas PT. Nusa Sarana Citra Bakti (Suzuki) Palembang bahwa setiap transaksi dibuktikan dengan adanya dokumen-dokumen. Dokumen tersebut berupa formulir dan surat-surat yang dikerjakan saat aktivitas berlangsung.

Pembuatan dokumen tersebut dimaksud untuk dikerjakan oleh bagian-bagian yang terlibat dalam aktivitas penjualan dan penerimaan kaspada PT. Nusa Sarana Citra Bakti (Suzuki) Palembang. Ini berarti batasan wewenang, tugas dan tanggungjawab dalam perusahaan sudah terlihat. Dokumen-dokumen tersebut lalu dicatat ke dalam buku jurnal apabila terjadi transaksi penjualan baik kredit maupun tunai secara harian. Transaksi penjualan yang terjadi dalam perusahaan ini dicatat dengan menggunakan buku penjualan. Setiap akhir bulan bagian akuntansi membuat laporan penjualan dengan maksud agar dapat membandingkan naik turunnya omset penjualan tiap bulan dan untuk mengetagui langganan yang belum melunasipiutangnya.

Secara harian transaksi perusahaan tersebut juga harus diposting ke buku besar, buku jurnal dan laporan penjualan, ini dilakukan untuk menghindari pekerjaan yang menumpuk serta keterlibatan akuntansinya. Selain itu bahwa posting harian akan menghindari kesalahan dalam mencatat transaksi yang sama, karena penulis menilai bahwa pencatatan transaksi penjualan dan penerimaan kas dalam PT. Nusa Sarana Citra Bakti (Suzuki) Palembang sudah menunjukkan kebaikan.

Selain itu agar perikiaraan-perkiraan yang diinginkan dapat dengan mudah dirumuskan perusahaan menggunakan pencatatan, pengelompokan dan pengintisaran transaksi oleh perusahaan dalam buku pedoman siklus akuntansinya. Penulis berpendapat bahwa informasi akuntansi yang dihasilkan akan lebih baik untuk pengambilan keputusan. Selain itu suatu keputusan akan lebih mudah diambil jika informasi yang dibutuhkan sudah tersaji dalam bentuk laporan, karena laporan merupakan media yang digunakan untuk memberikan informasi pelaksanaan suatu rencana.

Laporana keuangan yang dibuat PT. Nusa Sarana Citra Bakti (Suzuki) Palembangmeliputi Neraca, Laporan Laba Rugi. Penulis berpendapat bahwa informasi keuangan yang disajikan dalam Laporan Keuangan telah menunjukkan kelengkapan, dimana saldo awal dan perubahan saldo akhir suatu pos diungkapkan. Pada PT. Nusa Sarana Citra Bakti (Suzuki) Palembangjuga membuat intern yaitu laporan manajemen yang digunakan sarana pengendalian dan perencanaan.

\section{F. KESIMPULAN DAN SARAN}

1) Kesimpulan

Berdasarkan pembahasan mengenaiAnalisis Sistem Pengendalian Intern Terhadap Prosedur Penjualan dan Penerimaan Kas Pada PT. Nusa Sarana Citra Bakti (Suzuki) di Palembang dapat disimpulkan sebagai berikut:

Sistem pengendalian intern terhadap prosedur penjualan dan penerimaan kas pada PT. Nusa Sarana Citra Bakti (Suzuki) Palembang sudah baik akan tetapi pada prosedur tersebut masih tumpang tindih dengan tugas dan fungsi masing-masing. Dalam proses akuntansinya, perusahaan telah menggunakan media akuntansi yang memadai berupa dokumen dasar, buku jurnal, buku besar, buku pembantu. Untuk proses pengklasifikasian, perusahaan juga telah menggunakan kode perkiraan dimana kode perkiraan telah dibakukan dalam bentuk buku pedoman yang dilengkapi dengan penjelasan penggunaannya. Pelaporan dari sistem informasi akuntansi penjualan dan penerimaan kas terdiri dari laporan ekstern dan laporan 
intern manajemen.

2) Saran

Berdasarkan dari hasil penelitian dan pembahasan, dapat diajukan rekomendasi atau saran, yaitu dalam usaha memperketat pengawasan PT. Nusa Sarana Citra Bakti Palembang sebaiknya pimpinan perusahaan harus melakukan pemeriksaan secara tiba-tiba atas kebijakan-kebijakan yang ditetapkan pada karyawannya. Dalam hal penyerahan hasil penjualan kredit, sebaiknya langsung disetorkan kapada kasir, sehingga pembagian kerja dan tanggung jawab dapat dilaksanakan dengan sebaik-baiknya.

\section{DAFTAR PUSTAKA}

Astria, D., Faridah,\& Thanwain. (2017). Analisis Sistem Pengendalian Intern Kas pada PT Jjujur Jaya Sakti Makassar. Jurnal Riset Edisi XIII Unibos Makasar Vol 3, No. 002 Hal. 1-14 (2017) .

Bahari, Ivan Setyo. 2017. Analisis Sistem Akuntansi Penjualan Dan Penerimaan Kas Dalam Upaya Peningkatan Pengendalian Intern. Jurnal Administrasi Bisnis (JAB) Vol. 53 No. 1 Desember 2017

Hanny, Ibni. 2013. Analisis Sistem Pengendalian Intern Pengeluaran Kas Pada PT. Rohul Sawit Industri (RSI) Ujung Batu Rokan. Jurnal Ekonomi Bisnis

Herman, Lisa Amelia, 2013. Pengaruh keadilan organisasi dan sistem pengendalian intern terhadap kecurangan (studi empiris pada kantor cabang utama bank pemerintah di Kota Padang). Jurnal Akuntansi Vol 1 No 1 (2013) Universitas Negeri Padang

Krisnawati, A., Suhadak, S., \& Topowijono, T. (2013). Analisis Sistem Informasi Akuntansi Penjualan Dan Penerimaan Kas (Studi Pada Penjualan Speedy PT. Telekomunikasi Indonesia, Tbk Kandatel Malang). Jurnal Administrasi Bisnis S1 Universitas Brawijaya, 1(1), 59-67.

Manoppo, Rannita Margaretha. 2013. Analisis Sistem Pengendalian Intern Penerimaan Dan Pengeluaran Kas Pada PT. Sinar Galesong Prima Cabang Manado. ISSN 2303-1174. Jurnal EMBA. Vol.1 No.4 Desember 2013, Hal. 1007-1015

Oktariansyah, 2015. Evaluasi Struktur Organisasi Terhadap Pengendalian Intern Pada CV. Sedulur Palembang. Jurnal Media Wahana Ekonomika, Vol. 11, No.4, Januari $2015: 28-36$ 